\title{
Identifying factors influencing the low-income community in urban slum settlements in South Sumatera, Indonesia
}

\section{Suhel Suhel; Imam Asngari; Mardalena; Ariodillah Hidayat; Abdul Bashir}

Faculty of Economics, Universitas Sriwijaya, Indonesia

*To whom correspondence should be addressed. Email: abd.bashir@unsri.ac.id

\begin{tabular}{|l|l|l|l|l|}
\hline DOI: & Received: & Revised: & Accepted: & Published: \\
10.22437/ppd.v9i1.10385 & 31.08 .2020 & 31.01 .2021 & 27.02 .2021 & 30.04 .2021 \\
\hline
\end{tabular}

\begin{abstract}
The study is identifying factors influencing the low-income community in urban slum settlements in South Sumatra. The data utilized is primary data is taken through surveys and in-depth interviews. The samples were taken from 115 respondents purposively in the three cities of Palembang, Prabumulih, and Pagar Alam that are receiving benefits from the KOTAKU Program. The methods utilized are descriptive qualitative and quantitative approaches by applying multiple regression models. This study's findings indicate that jointly the variables of education level, age, family members, income expectations, and work types significantly affect the low-income communities' income level. Likewise, partially the education level variables, the family members, income expectations, and types of work positively and significantly affect income level. In contrast, the age variable has a negative and significant effect on the low-income community's income level in urban slums of South Sumatra.
\end{abstract}

Keywords: Low-income community, Prosperity, Urban slum, Welfare, Indonesia

JEL Classification: P14, P25, R14, R20.

\section{INTRODUCTION}

The development of economic activities in urban areas is undeniably directly proportional to the community's welfare level. Besides, the urban economy's stretching is the main attraction as one reason for the individual to urbanization (Hussain \& Imitiyaz, 2019; Leon, 2008). This condition raises the problems such as limited city capacity, crime, cleanliness/rubbish, health, and slums in the urban areas.

Slums in the city become a problem that requires serious attention from the government. The settlements can be viewed from land, housing, community, basic facilities, and infrastructure, which are intertwined in a socio-economic and cultural system both in a slum environment ecosystem itself or a city ecosystem. Slums must be viewed in their entirety and intellectually in a broader dimension. According to Sastra, Suparno, \& Marlina (2006), several dimensions of slums that must always receive serious attention are land issues in urban areas, basic infrastructure and facilities issues, socio-economic problems, socio-cultural issues, urban spatial issues, accessibility issues (Yuliana et al., 2017).

The challenge for developing cities lies in the proper and inclusive management of slum settlements if the area is to progress in a sustainable manner (Tannerfelt \& Ljung, 2006). It is also related to social, physical, social change, economy, politics, and urban environment. The cities function as multi-dimensional and multi-dimensional 
machine rooms for human development (Nocca, 2017). The well-developed cities have always been attractive for residents looking for opportunities (Abubakar et al., 2019; Agnihotri, 1994; Glaeser, 2011).

The main purpose of moving or living in the city is to improve welfare and a better life. However, urban slums have always been a relatively easy source of living, accessible, and often permanent residence for the poor or the less fortunate. The urban area is paving the way to prosperity; the other side of the city is also causing inequality, economic and environmental challenges (Abubakar et al., 2019; Arimah, 2017; Nocca, 2017). Prosperity in urban areas is increasingly worrying. When it comes to slum settlements, poor governance and weak institutions can be linked. Herein lies the potential for engaging in this idea: for slums, cities have certain potentials for improvement and overall well-being; for the city, the way to achieve this goal is through prosperity (Abubakar et al., 2019).

The concept of prosperity has recently been studied as a significant measure of the life of a country, city, or population (Abubakar et al., 2019). Recent progress in understanding prosperity has been threefold: first, it recognizes that from a welfare perspective, prosperity is not only linked to economic growth - an aspect highlighted by the long-standing economic monopoly on the general concept of prosperity (Abubakar et al., 2019; De Snyder et al., 2011). Instead, it also concerns social and environmental criteria that address the growing gap between rural and urban areas. On the other side, prosperity is a relative concept rather than an absolute one (Abubakar et al., 2019; Yuliana et al., 2017).

Slum settlements in urban areas are always associated with the lack of availability of access to facilities and infrastructure, economic and social access, and the behavior of people whose majority of the population has low income (Ferrer et al., 2018; Parvin et al., 2016). To ensure sustainable slum upgrading needs to be supported by sustainable livelihoods, the government has a city without slum (KOTAKU) program. The program focuses on increasing the low-income community's capacity (MBR) in converting assets into income through synergies between increasing the pentagonal assets of low-income communities and developing the local economy.

This program is one of the government's strategic efforts to accelerate the handling of urban slums. This program utilized a collaborative platform between the central government, provincial governments, local governments, communities, and stakeholders by positioning the community and local government as the main actors. Funding for this program comes from the central government, provincial governments, local governments, non-government organizations, stakeholders, and government development partners such as the World Bank, the Asian Infrastructure Investment Bank, and the Islamic Development Bank. The funding source from government development partners (loans) is around $45 \%$ of the total financing needs.

The related studies have conducted by Siregar (2013) indicated that the level of community willingness to receive the benefits of the Urban Land Consolidation program was quite high at $64 \%$. The significant variables influential to receive the program urban land consolidation are age, gender, work, area of origin, number of families, land area, number of building floors, length of stay, age of the building, number of rooms, the guarantee of getting property right certificate (SHMRSS) and a guarantee of compensation for relocation costs. Furthermore, Sastanti \& Fibriani (2019) found that the priority factors for riverbank slum areas are urban land factors, spatial factors, and building ownership status factors. Priority factors that influence dense urban slums are urban land factors, spatial factors, and economic factors (Mahamud et al., 2016). Simultaneously, the priority factors that influence slum areas along the 
railroad tracks are the building's ownership status, economic factors, and spatial factors (Krisandriyana et al., 2019).

Krisandriyana et al. (2019) found that slum areas in Surakarta city consist of three typologies, namely slum areas along the riverbanks, densely populated urban slum areas, and slum areas along the railroad tracks. This area is relatively neglected due to the decline in its physical, socio-economic, and socio-cultural qualities. These settlements are inhabited by a poor society that is densely populated and has minimal infrastructure. Many factors can affect slum areas, and these factors include urbanization, infrastructure, economy, urban land, spatial planning, urban attractiveness, socio-cultural, building ownership status, and length of stay (Chirisa, 2010; Esch et al., 2014).

On the other hand, the study conducted by Handito \& Imron (2015) showed that meeting the poor's food needs depends on daily income. Therefore the poor have a way to be able to survive with low and uncertain income. Meanwhile, Dyah et al. (2010) that the development guidance (arrangement directions) involves the improvements of settlement infrastructures such as procurement of open green space facilities, the quality, and quantity of clean water supply, improvement of drainage facilities, and garbage disposal systems. Intensity settings of buildings in residential areas in the form of restrictions on KDB (Basic Building Coefficient) 70\% and KLB (Building Floor Coefficient) $140 \%$ and controlling trade area intensity. The arrangement of social and economic improvement to minimize the Tunjungan square settlement problems and optimize the Tunjungan square area's potential.

Additionally, the results of the study by Heston \& Yusuf (2013) explain that the success of social assistance in the rearrangement of urban slums depends on increasing the capacity of government governance and community. Valuable study on developing countries that deserve consideration has been carried out by Samuel et al. (2017). His study found that the relationship between the poor and friends, family, and communities in slum settlements was the main factor for this cluster's difficulty to move on of poverty because most of these clusters valued their social connectedness intrinsically. Therefore, social connectedness is an important factor that needs to be considered in overcoming multi-dimensional poverty effectively in certain clusters.

This study refers to the sustainable livelihood model (SL model). This approach explains three insights about poverty that underlie this approach (Krantz, 2001). The first is the awareness that although economic growth may be important for poverty reduction, there is no direct relationship between the two because it all depends on the poor's ability to take advantage of economic opportunities. Second, there is an awareness that the poor understand poverty is a problem of low income and includes other dimensions such as low education, poor health, lack of social security, and others. Third, the poor themselves are often best informed of their situation and needs and must design policies and projects to improve their lot. There is no integrated approach to implementing the SL model. this approach can be used as an analytical framework for program assessment, such as implementing the KOTAKU program. However, three basic features are common to most approaches (Krantz, 2001). First, the focus is on the livelihoods of the poor. The second is that this approach can reject standard procedures from conventional approaches that take certain sectors such as agriculture. Third, the SL approach emphasizes programs that involve all parties, such as the government, community organizations, and government development partners, to identify and implement a policy program.

In this regard, this study focuses on the level of welfare of low-income people in urban slum areas. As explained in the previous introduction, this research is still interesting because it focuses on slum settlements that target the KOTAKU program in 
the province of South Sumatra, such as Palembang, Prabumulih, and Pagar Alam city. Therefore this study aims to identify factors that affect the low-income community in urban slum settlements. These factors are reviewed from socio-economic variables such as education level, age, type of work, family member, and income expectations. In the next section, we describe the research method, results and discussion, and finally, this study's conclusions.

\section{METHODS}

This study's concentration on the low-income community in urban slums as targets of the KOTAKU program in South Sumatera Province. The study location is three cities receiving the KOTAKU Program namely Palembang, Prabumulih, and Pagar Alam. The samples were taken as much as 10 percent of households at ten urban villages. This urban village was taken based on considering that most households in urban villages are targets of the KOTAKU program.

The sample was taken as many as 115 respondents purposively, with an estimated precision of $90 \%$ of the surveyed samples. Data collection methods are surveys and indepth interviews with respondents. The respondents have the criteria of the low-income community below the poverty line of the Province of South Sumatra as of September 2018, i.e., earning IDR.441,049 per capita/month or earning IDR.2,035,988 per household per month. Data consist of qualitative and quantitative; the variable definitions and data measurements used in this study are presented in Table 1.

Table 1. Definitions of variables

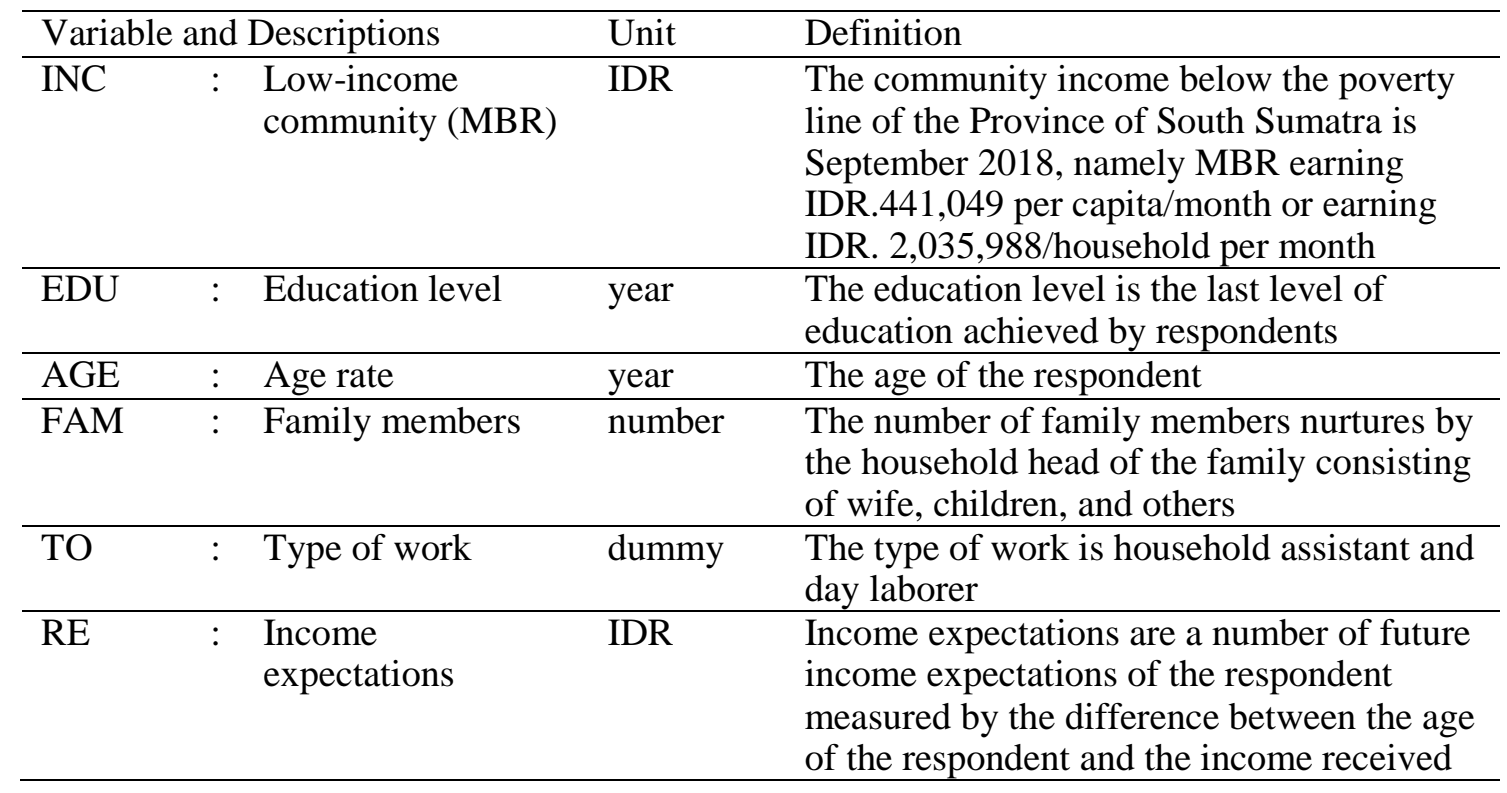

To analyze the factors affecting low-income communities in urban slum settlements, cross-tabulation and quantitative approaches utilized regression models with the ordinary least square method (OLS). The welfare function, which is proxied by income household, is a function of the following variables in equation 1:

$$
\mathrm{INC}=\mathrm{f}(\mathrm{EDU}, \mathrm{AGE}, \mathrm{TO}, \mathrm{FAM}, \mathrm{RE})
$$

Furthermore, the model specifications are as follows.

$$
\mathrm{INC}_{\mathrm{i}}=\alpha_{0}+\alpha_{1} \mathrm{EDU}_{\mathrm{i}}+\alpha_{2} \mathrm{AGE}_{\mathrm{i}}+\alpha_{3} \mathrm{TO}_{\mathrm{i}}+\alpha_{4} \mathrm{FAM}_{\mathrm{i}}+\alpha_{5} \mathrm{RE}_{\mathrm{i}}+\varepsilon_{i}
$$

Where: INC is the low-income community (IDR); EDU is education level (year); AGE is age rate (year); FAM is family members (person); RE is revenue expectations (IDR); TO is the type of work (dummy); $\alpha_{0}$ is constant-coefficient; $\alpha_{1,2,3,4,5}$ is coefficients of 
the parameters; and $\varepsilon_{\mathrm{i}}$ is the error term.

The forthcoming stage to evaluate and analyze the model estimation result based on three criteria. These are (1) diagnostic test of econometrics seen from OLS method violation tests including autocorrelation, heteroscedasticity, and multicollinearity tests; (2) statistical criteria seen from the coefficient value f-test and t-test; and (3) economic criteria seen from the consistency of sign on each coefficient of the independent variables whether accordance with the existing economic theory and previous studies.

\section{RESULTS AND DISCUSSION}

\section{Socio-economic conditions of low-income communities in urban slums}

According to the Central Statistics Agency (BPS), slums are areas of a residence inhabited by communities in slum settlements that occupy temporary buildings, no access to safe water to drink, lack of proper sanitation facilities, and inadequate environmental conditions. Furthermore, the World Bank (1999) explains that slums are an overlooked part of urban development. It is indicated by the socio-demographic conditions in slums, such as high population density, environmental conditions that are not livable and satisfy the requirements, and the lack of educational facilities, health, and socio-cultural infrastructure. The main factor for the growth of slums is the incessant rural-urban drifts. The following explained the income level based on socioeconomic characteristics of household head in urban slums in South Sumatra, using the cross-tabulation as follows:

Table 2. Income level based on education level respondents in urban slums (percent)

\begin{tabular}{lccc}
\hline \multirow{2}{*}{ Education level } & \multicolumn{3}{c}{ Income level (in rupiah) } \\
\cline { 2 - 4 } & $<1$ million & $1-2$ million & $>2$ million \\
\hline Incomplete primary school & 48.33 & 3.03 & 0.00 \\
Primary school & 30.67 & 12.12 & 0.00 \\
Junior high school & 12.13 & 15.15 & 0.00 \\
Senior high school & 8.87 & 60.6 & 48.00 \\
Bachelor degree & 0.00 & 9.09 & 52.00 \\
\hline
\end{tabular}

In Table 2, it can be seen that respondents with an education level that incomplete primary school are 48.33 percent on average earning less than IDR.1,000,000 per month. On the other hand, respondents with a high school education are 60.6 percent, with an average income of between IDR.1,000,000-2,000,000 per month. It showed that the importance of education in the family. Education is believed to be very influential on one's skills, behavior, and attitudes and influences one's income level.

Table 3. Income level based on the age of respondents in urban slums (percent)

\begin{tabular}{lrcc}
\hline \multirow{2}{*}{ Age rate (year) } & \multicolumn{3}{c}{ Income level (in rupiah) } \\
\cline { 2 - 4 } & $<1$ million & $1-2$ million & $>2$ million \\
\hline less than 30 year & 60.00 & 40.00 & 0.00 \\
between 30 - 60 year & 42.57 & 56.43 & 0.99 \\
more than 60 year & 75.00 & 25.00 & 0.00 \\
\hline
\end{tabular}

A person's productivity at work is influenced by age. Generally, someone of productive age will earn more income than someone of non-productive age. This age structure will affect the economic activities carried out by that person. Respondents in the range of 30 to 60 years, as much as 56.43 percent, have income between IDR.1,000,000-2,000,000 per month. This condition showed a direct relationship between the productive age and the respondents' income level (Table 3). 
Table 4. Income levels based on family members in urban slums (percent)

\begin{tabular}{lccc}
\hline \multirow{2}{*}{ Family members (persons) } & \multicolumn{3}{c}{ Income level (in rupiah) } \\
\cline { 2 - 4 } & $<1$ million & $1-2$ million & $>2$ million \\
\hline less than 3 persons & 40.00 & 55.00 & 5.00 \\
between 3 - 5 persons & 38.36 & 54.79 & 0.00 \\
more than 5 persons & 45.45 & 54.54 & 0.00 \\
\hline
\end{tabular}

In Table 4, as much as 54.79 percent of respondents earn between IDR. $1,000,000-2,000,000$ and have family members between 3 to 5 persons. In theory, the number of family members will motivate someone to work hard to meet the needs of their family life

Table 5. Income levels based on the type of work in urban slums (percent)

\begin{tabular}{lccc}
\hline \multirow{2}{*}{ Type of work } & \multicolumn{3}{c}{ Income level (in rupiah) } \\
\cline { 2 - 4 } & $<1$ million & $1-2$ million & $>2$ million \\
\hline Household assistant & 72.00 & 28.00 & 0.00 \\
Daily laborer & 78.72 & 21.28 & 0.00 \\
\hline
\end{tabular}

Based on Table 5, the average respondent earns less than IDR.1,000,000, with the type of work being processed household assistant and daily laborers. The rest will earn between IDR.1,000,000-2,000,000. This condition showed that most respondents work in the informal sector.

\section{Determinants of income levels of low-income communities in urban slums}

The diagnostic test using serial correlation (LM test) Breusch-Godfrey criteria shows that the probability of chi-squares value of 0.491 greater than the significant level of 0.05 . It means the model does not experience autocorrelation problems Autocorrelation test. Furthermore, using the Heteroskedasticity test: ARCH, obtained chi-squares probability value of 0.732 greater than the significant level of 0.05 , then Ho is accepted, which means the model does not experience the problem of heteroskedasticity. All variables have a value of variance inflation factor (VIF) $<10$, concluded free of multicollinearity.

Table 6. The result of model estimation

\begin{tabular}{|c|c|c|c|c|c|}
\hline \\
\hline \multicolumn{2}{|c|}{$\begin{array}{l}\text { Dependent variable }=\text { INC } \\
\text { Variable }\end{array}$} & Coefficient & t-test & Sig. & VIF \\
\hline $\mathrm{C}$ & Constant & $\begin{array}{l}15.978 * * * \\
(3.174)\end{array}$ & 3.174 & 0.000 & - \\
\hline EDU & Education level & $\begin{array}{c}0.060 * * * \\
(0.024)\end{array}$ & 2.465 & 0.015 & 1.248 \\
\hline AGE & Age rate & $\begin{array}{c}-7.826 * * * \\
(-0.913)\end{array}$ & -8.563 & 0.000 & 1.112 \\
\hline TO & Type of work & $\begin{array}{c}4.335 * * * \\
(1.528)\end{array}$ & 2.836 & 0.000 & 1.166 \\
\hline FAM & Family members & $\begin{array}{l}4.041 * * * \\
(0.412)\end{array}$ & 9.787 & 0.000 & 1.226 \\
\hline RE & Revenue expectations & $\begin{array}{c}1.231 * * * \\
(0.112)\end{array}$ & 10.982 & 0.005 & 1.175 \\
\hline $\begin{array}{l}\mathrm{R}^{2}=0.8 \\
\text { LM-test }\end{array}$ & $\begin{array}{l}\mathrm{F}_{\text {statistic }}=125.066 ; \mathrm{Pr} \\
808[0.491] ; \mathrm{ARCH}-\mathrm{t}\end{array}$ & $\begin{array}{l}\text { ic) }=0.000 ; \mathrm{D} \\
35[0.732]\end{array}$ & $=1.8$ & & \\
\hline
\end{tabular}

To determine the effect of education level, age, family members, income expectations, and type of work on income level in urban slums in South Sumatra 
Province. The estimation model results show that the f-test value is 125.066 , and the probability value of 0.000 is smaller than the significance level of 0.05 . So, it can be stated that independent variables, i.e., the education level, age, family members, type of work, and income expectation, significantly influence the level of the income level of low-income community families in urban slums areas. It also can be seen from the coefficient of determination $\left(\mathrm{R}^{2}\right)$ of 0.8515 . It means that variations in the low-income community's income level in urban slums explain by the variation of the independent variables are 85.15 percent, the remaining 14.85 percent is determined by the variation of other variables outside the model used in this study.

\section{The effect of education on income level}

The estimation results obtained the coefficient value of the education level variable of 0.060 , and the probability value of 0.015 is smaller than the significant level of 0.05 . Thus, the educational variable significantly influences low-income community families' income in urban slum areas in South Sumatra Province. It means that the hypothesis that there is an effect of education on individuals' income level in the slum areas of South Sumatra Province is accepted. The education level was one measure of a person's quality; the higher a person's education, the more rational thinking. The estimation results show the value of the respondent education level coefficient was 0.060 , and the effect was positive on family income. It means that if there is an increase in one level of education for each individual, the income received will increase by 0.060 or 6 percent. This seen that respondents with an education level did not complete primary school as many as 48.33 percent with an average income of less than IDR. 1,000,000 per month.

On the other hand, respondents with a high school education are 60.6 percent, with an average income of between IDR.1,000,000-2,000,000 per month. Education is believed to be very influential in one's skills, behavior, and attitudes and influences one's income level. It means that the higher a person's level of education, the more it is possible to obtain a higher income. The study results support this finding by Putri \& Setiawina (2013) and found evidence that education level has a significant effect on income levels.

\section{The effect of age on income level}

The estimation results obtained statistically show that the coefficient value of 7.826 and a probability value of 0.000 smaller than the significance level of 0.05 . Thus, the age variable has a negative sign and a significant effect on income level in urban slum areas. It means that the hypothesis stating that there was an influence of age on low-income community families' income in the urban slums of South Sumatra is accepted. A person's productivity at work is greatly influenced by age. A general individual who was at a productive age will earn more income than an individual is of non-productive age. From the regression model's estimation results, the coefficient of the age variable value of -7.826 means that if during the productive age, the income level will rise. But if the age was no longer productive, there was a decrease in the level of income. Therefore the direction of the coefficient value of the age variable is negative. It was supported by Julianto \& Utari (2017); the study found that age has a positive sign and significant effect on income level.

\section{The effect of type of work on income level}

From the estimation results obtained statistically, the work type's coefficient value is 4.335 , and the probability value of 0.005 smaller than the 0.05 significance level. Thus, the variable type of work is significant and positively influences the income level in urban slum areas. The type of work performed will determine the income received by 
respondents. Also, the type of work a person will see by the skills possessed. From the data processing results, the work type coefficient is 4.335 , and the effect is significant. It means that respondents have different types of work as a determinant of the level of income received.

\section{The effect of family members on income level}

The estimation results obtained the coefficient value of the family members variable of 4.041 and a probability value of 0.000 smaller than the significance level of 0.05 . Thus, the family members variable has a positive sign and significant effect on the income level in urban slum areas. The hypothesis states that family members' influence on income level in urban slums is accepted. Family members were the obligation of the head of the family to meet the family's living needs. The greater the family members, the family head should be more motivated to earn a living earning his family income. From the estimation results, it can be seen that the coefficient value of the family members variable is 4.041, meaning that if there is an addition of 1 person of the family member, then the income level will rise by 4.04 percent. The coefficient value reflects the relationship condition between family members and the income level received. This finding was in line and supported the study conducted by Murti et al. (2017).

\section{The effect of income expectations on income level}

The calculation results obtained the coefficient value of the income expectations statistically variable is 1.231 and a probability value of 0.000 smaller than the 0.05 significance level. Thus, the income expectation variable significantly influenced lowincome community families' income in urban slum areas. It means that the hypothesis stating that there was an influence of income expectations on the income level in the urban slums is accepted. Theoretically, consumption of the live cycle hypothesis states that future income expectations will determine the amount of consumption expenditure. It was certainly related to a person's age. The income expectation variable is significant but has a negative effect on respondents' level of income, with a coefficient value of 1.231. It means that the higher income expectations, the higher the level of income received by respondents.

\section{CONCLUSIONS AND RECOMMENDATIONS}

\section{Conclusions}

More than half (52.17 percent) of low-income people in urban slum areas in South Sumatra have a high school education, and the rest (44.33 percent) have a junior high school education and below. As many as 87.83 percent were between the ages of 30 to 60 years, the remaining 8.7 percent and 3.48 percent, respectively, aged less than 30 years and more than 60 years. This condition shows that relatively many were in the range of productive age or working age.

Then as much as 63.48 percent of respondents have family members between 3 to 5 persons. The rest are less than 3 and above 5 individuals, respectively 17.39 percent and 19.13 percent. As many as 40.87 percent work as casual daily laborers, work in the home industry, the type of work carried out, as much as 24.35 percent, and open processed food stalls as much as 21.74 percent. Because of limited ability thus, the type of work performed is relatively limited, mostly working in the informal sector.

The variables of education level, age, family members, income expectations, and work type significantly affect the low-income community's income level in urban slums. Likewise, partially education variables, family members, income expectations, and work types positively affect the low-income community's income level. In contrast, the age variable negatively affects income level in urban slums. 


\section{Recommendations}

We offer the need for great urban spatial planning by the local government so that urban slum settlements can be controlled. The KOTAKU program is one of the right strategies. Still, it needs support from many parties, especially the program's main actors are local governments and communities in urban slum settlements. This program adopts a sustainable livelihood approach by applying a collaborative approach between the central government, local governments, stakeholders, non-governmental organizations, and local government development partners such as the World Bank, the Asian Infrastructure Investment Bank, and the Islamic Development Bank.

Additionally, the program's main activities, starting from providing livable houses affordable for low-income communities in urban slum areas, enhance the public facilities in structuring activities in urban slum areas such as building the facilities and infrastructure needed by the community. This program activity also aims to form regional business units that aim to improve the quality of social structuring slums. Increase community capacity is done with citizens' commitment, active involvement in decision-making, planning, implementation, maintenance, monitoring, and improving social contribution quality in structuring slum priority. On the other hand, urbanization control needs to be improved by strengthening economic institutions supporting rural development. Furthermore, future research requires expanding the research scope, for example, in cities in South Sumatra. Besides that, it can develop a model by adding other socio-economic variables.

\section{REFERENCES}

Abubakar, A., Romice, O., \& Salama, A. M. (2019). Slums and prosperity: a complex, dynamic pathway of intervention. Archnet-IJAR, 13(2), 314-330.

Agnihotri, P. (1994). Poverty Amidst Prosperity. MD Publications Pvt Ltd.

Arimah, B. (2017). Infrastructure as a Catalyst for the Prosperity of African Cities. Procedia Engineering, 198, 245 - 266.

Chirisa, I. (2010). Peri-urban dynamics and regional planning in Africa: Implications for building healthy cities. Journal of African Studies and Development, 2(2), 1526.

De Snyder, V. N. S., Friel, S., Fotso, J. C., Khadr, Z., Meresman, S., Monge, P., \& Patil-Deshmukh, A. (2011). Social conditions and urban health inequities: Realities, challenges and opportunities to transform the urban landscape through research and action. Journal of Urban Health, 88(6), 1183-1193.

Dyah, R. W., Kurniawan, E. B., \& Usman, F. (2010). Penataan Permukiman di Kawasan Segiempat Tunjungan Kota Surabaya. Jurnal Tata Kota Dan Daerah, 2(2), 1-8.

Esch, T., Marconcini, M., Marmanis, D., Zeidler, J., Elsayed, S., Metz, A., Müller, A., \& Dech, S. (2014). Dimensioning urbanization - An advanced procedure for characterizing human settlement properties and patterns using spatial network analysis. Applied Geography, 55, 212-228.

Ferrer, A. L. C., Thomé, A. M. T., \& Scavarda, A. J. (2018). Sustainable Urban Infrastructure: A review. Resources, Conservation and Recycling, 128, 360-372.

Glaeser, E. (2011). Triumph of the City. Penguin Books.

Handito, R. K., \& Imron, A. (2015). Strategi Pemenuhan Kebutuhan Pangan Masyarakat Miskin Di Wilayah Slum Dukuh Kupang Barat - Surabaya. Paradigma, 3(1), 1-5.

Heston, Y. P., \& Yusuf, A. (2013). Penguatan Kemampuan Sosial Pada Penataan Kawasan Kumuh Perkotaan (Studi Kasus KelurahanCigugur Tengah Cimahi). Tataloka, 15(3), 208-217. 
Hussain, M., \& Imitiyaz, I. (2019). Urbanization Concepts, Dimensions and Factors. International Journal of Recent Scientific Research, 9(1) 23513-23523.

Julianto, D., \& Utari, P. A. (2017). Analisa Pengaruh Tingkat Pendidikan terhadap Pendapatan Individu di Sumatera Barat. Ikraith Ekonomika, 2(2), 122-131.

Krantz, L. (2001). The Sustainable Livelihood Approach to Poverty Reduction: An Introduction. Division for Policy and Socio-Economic Analysis, Swedish International Development Policy.

Krisandriyana, M., Astuti, W., \& Fitriarini, E. (2019). Faktor Yang Mempengaruhi Keberadaan Kawasan Permukiman Kumuh di Surakarta. Jurnal Desa - Kota, $1(1), 24-33$.

Leon, D. A. (2008). Cities, Urbanization and Health. International Journal of Epidemiology, 37(1), 4-8.

Mahamud, M. A., Samat, N., \& Noor, N. M. (2016). Identifying factors influencing urban spatial growth for the George Town Conurbation. Planning Malaysia, 14(November), 95-106.

Murti, D., Fathorrazi, M., \& Muslihatinningsih, F. (2017). Faktor yang Mempengaruhi Pendapatan Keluarga Miskin di Kecamatan Maesan Kabupaten Bondowoso. Jurnal Ekonomi Bisnis Dan Akuntansi, 4(2), 182-186.

Nocca, F. (2017). The Role of Cultural Heritage in Sustainable Development: Multidimensional Indicators as Decision-Making Tool. Sustainability, 9, 1882.

Parvin, G. A., Shaw, R., \& Shumi, K. F. (2016). Urban Disasters and Microfinancing. In R. Shaw, Atta-ur-Rahman, A. Surjan, \& G. A. Parvin (Eds.), Urban Disasters and Resilience in Asia (pp. 141-159). Butterworth-Heinemann.

Putri, A. D., \& Setiawina, D. (2013). Pengaruh Umur, Pendidikan, Pekerjaan Terhadap Pendapatan Rumah Tangga Miskin di Desa Bebandem. E-Journal Ekonomi Pembangunan, 2(4), 173-225.

Samuel, K., Alkire, S., Zavaleta, D., Mills, C., \& Hammock, J. (2017). Social Isolation and its Relationship to Multi-dimensional Poverty. Oxford Development Studies, 46(1), 83-97.

Sastanti, S. Y., \& Fibriani, C. (2019). Analisis Tingkat Permukiman Kumuh Menggunakan Metode AHP Berbasis SIG pada Kota Magelang. Jurnal Nasional Teknologi Dan Sistem Informasi, 5(1), 69-78.

Sastra, M., Suparno, \& Marlina, E. (2006). Perencanaan \& Pengembangan Perumahan. Yogyakarta: Penerbit Andi.

Siregar, M.A. (2013). Analisis Kesediaan Masyarakat Menerima Program Konsolidasi Tanah Perkotaan pada Kawasan Permukiman Kumuh Berat. Aspirasi, 4(2), 101117.

Tannerfelt, G., \& Ljung, P. (2006). More Urban Less Poor: An Introduction to Urban Development and Management. Routledge.

Yuliana, S., Yunisvita, Yulianita, A., Muhyiddin, N. T., \& Bashir, A. (2017). The Linkage of Human and Money Flows to Rural-Urban Fringe Poverty in South Sumatra, Indonesia: In an Islamic Perspective. International Journal of Economics and Financial Issues, 7(4), 237-243.

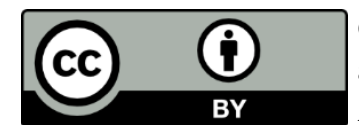

(C) 2021 by the authors. Licensee JPPD, Indonesia. This article is an open-access article distributed under the terms and conditions of the Creative Commons Attribution (CC BY) license (http://creativecommons.org/licenses/by/4.0/). 